\title{
USE OF POLYMERASE CHAIN REACTION FOR DIAGNOSIS OF BOVINE CORONAVIRUS IN DIARRHEIC CALVES
}

\author{
Nahed, A. Mahmoud"; Hanaa, A. M. Ghoneim ${ }^{* *}$,Hala, A. Salem* \\ * Animal Health Research Institute, Dokki, Giza. \\ ** Animal Reproduction Research Institute, Al-Harram, Giza.
}

\begin{abstract}
ABESTRACT
Bovine Corona virus (BCV) is the main cause of diarrhea in many animal species world wide. Calves up to 3 months old can be affected by this virus. The importance of $B C V$ in cattle industry is due to economic loss, treatment costs, and reduced growth rate in beef and dairy calves. This study dimed to examine 68 fecal samples(50 from diarrheic and 18 from non diarrheic calves) by using reversed transcriptase-polymerase chain reaction (RT-PCR), antigen capture enzymes linked Immunosorbent Assay (ELISA),direct Flourescent antibody test (FAT) and Haemagglutination and Haemagglutination inhibition technique (HAT/HIT) for detecting of BCV in diarrheic and non diarrheic calves. The highest percentage of $B C V$ in diarrheic calves by RT-PCR was $84 \%$ then $76 \%$ by using BCV antigen capture ELISA then $62 \%$ by direct FAT and the lowest percentages was $56 \%$ by HIT. Also the apparent prevalence of $B C V$ in non diarrheic calves were $44.4 \%$ by RT-PCR 27.7 by antigen capture ELISA, 22.2\% by direct FAT and $11.1 \%$ by HIT respectively. These results suggested that RT-PCR is more sensitive than other diagnostic methods to detect $B C V$, especially in subclinical cases.
\end{abstract}




\section{INTRODUCTION}

Bovine Corona virus (BCV) is a member of coronaviridae family, causes severe newborn calves diarrhea and is associated with winter dysentery with heamorrhagic diarrhea in adult cattle (Saif, 1990;Clark, 1993). Winter dysentery (WD) is characterized by a sudden onset of diarrhea that rapidly affects many adult cattle in a herd has been reported in many parts of the world.

Corona virus one of the most important economic viruses (Lathrop et al., 2000), WD-affected cattle lose body condition and results in a dramatic decrease in milk production (Traven. et al., 2001). BCV was first recognized as a cause of potentially fatal diarrhea of neonatal calves in 1972, and respiratory tract infections in cattles of various ages, that infect upper and lower parts of the tract, including bovine respiratory disease complex or shipping fever of feed lot cattle (Quinn et al ., 2002). Corona viruses also have been detected in feces from other diarrheic wild ruminants (Hasey et al., 1984; Tsunemitsu et al., 1995).

Bovine Corona viruses are pleomorphic with a diameter of $120 \mathrm{~nm}$ possesses a single-stranded, enveloped, non-segmented RNA genome with positive polarity (Varies et al., 1997). The virion contains five structural proteins, the nucleocapsid $(\mathrm{N})$, the transmembrane $(\mathrm{M})$, the heamagglutinin / esterase (HE), the spike (S) and the small membrane (E) protein (Saif, 1993). The BCV-N protein is a $50-60 \mathrm{KD}$ phosphoprotein that is bound to viral genomic RNA to form helical nucleocapsid . $\mathrm{N}$ - protein may play a role in replication of viral RNA since the antibody directed against the $\mathrm{N}$. protein inhibits the in vitro 
RNA polymerase chain reaction (Lai and Cavanagh, 1997). There are different methods to detect BCV but a high degree of sensitivity is required, especially in subclinically infected calves and chronic shedder of BCV in faeces. These calves are important sources for the infection of other calves (Hasuksuz et al., 2002).

The RT-PCR assay is useful to detect small quantities of nucleic acid and is widely used for the diagnosis of infectious disease.

This study was designed with two aims. The first was to determine the prevalence of BCV in a diarrheic and non diarrheic calves in a dairy herd at Ismaillia governorates, Egypt. The second was to compare RTPCR method to heamagglutination inibition, FA and ELISA techniques in relation to its sensitivity.

\section{MATERIALS AND METHODS}

\section{*Fecal samples:}

A total of 68 faecal samples from diarrheic (50 samples) and non diarrheic calves (18 samples) of up to 3 months of age belonged to a dairy herd at Ismaillia governorate, samples were collected directly from rectum in sterile bottle with $0.01 \mathrm{M}$ phosphate buffered saline (PBS) PH 7.2 and centrifuged at $3000 \mathrm{rpm}$ for $15 \mathrm{~min}$ at $4{ }^{\circ} \mathrm{c}$. the supernatant stored at -70 until analysis.

\section{* Virus:}

Standard Mebus strain of bovine coronavirus. The strain was obtained from Dr.linda Saif 's laboratory in Ohio Agricultural research and development centre, Wooster, USA, were stored at $-80^{\circ} \mathrm{c}$ in (AHRI) virology department. 
* Tissue culture:

Madain Darby Bovine kidney (MDBK) cell culture was obtained from virology department, Animal Health Research Institute, Dokki, Giza, Egypt.

\section{* Control sera:}

- Positive and negative bovine sera against BCV, was supplied by virology department, Animal Health Research Institute, Dokki, Giza.

- Standard anti bovine coronavirus conjugated with FITC used in direct FAT supplied by central Vet. Lab. New. Haw. Webridge, UK.

\section{* Haemagglutination test (HAT):}

The method used according to Hasoksuz et al.,(1999).

\section{*Haemagglutination Inhibition test (HIT):}

The field samples were tested as described by Sato et al ., (1977) using 96-well U-bottom plates with $50 \mu \mathrm{l}$ of $0.01 \mathrm{~m}$ PBS ( PH 7.4) supplemented with $0.2 \%$ bovine serum albumin. Add $50 \mu 1$ of each tested samples in the first wells of the plate and mixed well in the buffer then two-fold serial dilution were applied and the last $50 \mu \mathrm{l}$ were decanted, $50 \mu \mathrm{l}$ of standard anti-bovine corona virus was added to each well, the plate was incubated for half an hour at room temp. , $50 \mu \mathrm{l}$ of $0.5 \%$ mouse erythrocyte was added to each well of the plate. Mouse erythrocyte and virus controls were included. For mouse erythrocyte control, equal volume of $0.5 \%$ mouse erythrocyte and buffer was dispensed in one column. Covered the plate and incubated at $4{ }^{\circ} \mathrm{c}$ for two hours.The end point was the highest dilution which prevent completely the agglutination of RBCs. 
* Direct Fluorescent antibody test (FAT):

According to Payment and Trudel (1993), the test was carried out on fixed inoculated cell.

\section{* ELISA kits for BCV antigen detection:}

The kits is designed for antigenic detection of coronavirus in bovine faeces by ELISA supplied by Cypress Diagnostics.

\section{Principle of the test:}

The test uses 96-well microtitration plates coated by specific antibodies for the coronavirus, these antibodies allow a specific capture of the corresponding pathogens, which are present in the faeces samples Rows A,C,E,G have been sensitized with these antibodies and Rows $\mathrm{B}, \mathrm{D}, \mathrm{F}, \mathrm{H}$ are containing non specific antibodies. These control rows allow differentiation between specific immunological reaction and non specific binding to eliminate false positive.

\section{Procedure:}

1. Faecal samples was diluted volume per volume into dilution buffer.

2. $100 \mu \mathrm{l}$ aliquots of diluted samples was added to the wells as follow : sample 1 in wells A1 and B1, sample 2 in $\mathrm{C} 1$ and D1 etc. proceed in the same manner for the control antigen (ex.G1 and H1)

3. The plates incubated at room temp. $\left(18-25^{\circ} \mathrm{c}\right)$ for 1 hour.

4. The plates was washed by washing solution.

5. $100 \mu \mathrm{l}$ of the conjugate was added to each well, and plates incubated at room temp. for 1 hour. 
6. The plates washed with washing solution.

7. $100 \mu \mathrm{l}$ of chromogen added to each well and incubated the plates for 10 minutes at room temp. away from light.

8. $50 \mu \mathrm{l}$ of stop solution was added to each well.

9. The reading of the plate was at $450 \mathrm{~nm}$

\section{* Preparation of oligonucleotide primers:}

The oligonucleotide primers used in the RT-PCR were designed from published sequence of $\mathrm{N}$ gene of Mebus strain (Gen Bank accession No. M 16620). The sequence of primer pair was: $5 \square$-GCAATCCAGTAGTAGAGCGT-'3 (21-40), and:5'-CTTAGTGGCATCCTTGCCAA-3' (731-750).The predicated RT-PCR product size was $730 \mathrm{bp}$ specific for BCV supplied by (promega).

\section{* RNA extraction and RT-PCR :}

RNA from faeces was extracted using QIA amp virus RNA mini kit (Qiagen,U.K) as instructed by the manufacture.

The optimal annealing temperature was tested in a gradient thermocycler (Corbett, Australia) and used in the following protocols. We then optimized $\mathrm{Mg}++$ concentration and other conditions. For each sample we used neat and 1/10 diluted. The transcriptase reaction was conducted using the following procedure: in the tube $10 \mu \mathrm{l}$ of RNA samples was added at $70{ }^{\circ} \mathrm{c}$ for $5 \mathrm{~min}$ and then quenched on ice for $10 \mathrm{~min}$. 
Subsequently, $\mu 1$ of $5 \times$ RT buffer, $2 \mu 1$ of $0.1 \mathrm{M}$ dithiothereitol, 2 $\mu 1$ of $10 \mathrm{~m} \mathrm{M} \mathrm{dNTPS,} 20$ units of Rnase inhibitor (Fermentas, Germany) were added and with nuclease free water it was reached to $1 \mathrm{~g} \mu 1$. The mixture was incubated at $37^{\circ} \mathrm{c}$ for $5 \mathrm{~min}$. subsequently, 200 units of Moloney Murine Leukemia virus (M-Mulv) reverse transcriptase (Fermentase, Germany) were added and incubated at $70^{\circ} \mathrm{c}$ for $10 \mathrm{~min}$, and then quenched on ice for $5 \mathrm{~min}$. Five $\mu \mathrm{l}$ of the RT reaction samples were then added to $45 \mu \mathrm{l}$ of the PCR mixture. The PCR mixture consisted of $15 \mu \mathrm{l}$ of 10x PCR buffer, $2 \mu \mathrm{l}$ of $10 \mathrm{mM}$ dNTPS, $1 \mu 1$ of the up stream primer $(100 \mathrm{mM}), 1 \mu \mathrm{l}$ of the downstream primer, $35.5 \mu \mathrm{l}$ of water and $0.5 \mu 1$ of Taq polymerase (Fermentas, Germany) (5 units per $\mu 1)$. Then, $5 \mathrm{~min}$ of preheating at $94{ }^{\circ} \mathrm{c}, 35$ cycles, including $1 \mathrm{~min}$ at $94{ }^{\circ} \mathrm{c}, 1 \mathrm{~min}$ at $58^{\circ} \mathrm{c}, 2 \mathrm{~min}$ at $72{ }^{\circ} \mathrm{c}$ and finally, $7 \mathrm{~min}$ incubation at $72{ }^{\circ} \mathrm{c}$ were applied. The PCR products were visualized on 1.5 agarose gel stained with ethidium bromide PCR products of $730 \mathrm{bp}$ were detected (fig.2).

\section{RESULTS}

Results of the present study were summerized in table (1), the presence of $\mathrm{BCV}$ in the faecal samples of diarrheic calves in a higher percentage by RT-PCR (84\%) than by using of a BCV antigen capture ELISA $(76 \%)$ then FAT $(62 \%)$ and HIT $(56 \%)$ respectively. The HA titers was between 16-64. Figure (1) shows specific fluorescence observed in MDBK cells inoculated with faecal samples. Also the results of non diarrheic calves were parallel to the results of diarrheic calves whereas $44.4 \%$ were positive by RT-PCR, then $27.7 \%$ by ELISA, $22.2 \%$ by FAT and $11.1 \%$ by HIT respectively. According to the results, there was a significantly higher prevalence of coronavirus infection in diarrheic calves. 
Table (1): Detection of coronavirus antigen and RNA by different methods.

\begin{tabular}{|c|c|c|c|c|c|c|c|c|c|c|}
\hline $\begin{array}{l}\text { State of } \\
\text { animal }\end{array}$ & $\begin{array}{l}\text { Type of } \\
\text { samples }\end{array}$ & $\begin{array}{c}\text { Total No. } \\
\text { of samples }\end{array}$ & \multicolumn{2}{|c|}{ HIT results } & \multicolumn{2}{|c|}{ FAT results } & \multicolumn{2}{|c|}{ ELISA results } & \multicolumn{2}{|c|}{ RT-PCR results } \\
\hline \multirow{2}{*}{$\begin{array}{l}\text { Calves with } \\
\text { diarrhea }\end{array}$} & \multirow{2}{*}{$\begin{array}{c}\text { Fecal } \\
\text { samples }\end{array}$} & \multirow{2}{*}{50} & $+\mathrm{ve}$ & $\%$ & $+\mathrm{ve}$ & $\%$ & $+\mathrm{ve}$ & $\%$ & $+\mathrm{ve}$ & $\%$ \\
\hline & & & 28 & $56 \%$ & 31 & $62 \%$ & 38 & $76 \%$ & 42 & $84 \%$ \\
\hline $\begin{array}{c}\text { Calves } \\
\text { without } \\
\text { diarrhea }\end{array}$ & $\begin{array}{c}\text { Fecal } \\
\text { samples }\end{array}$ & 18 & 2 & $11.1 \%$ & 4 & $22.2 \%$ & 5 & $27.7 \%$ & 8 & $44.4 \%$ \\
\hline \multicolumn{2}{|c|}{ Total number } & 68 & 30 & $44.1 \%$ & 35 & $51.5 \%$ & 43 & $63.2 \%$ & 50 & $73.5 \%$ \\
\hline
\end{tabular}

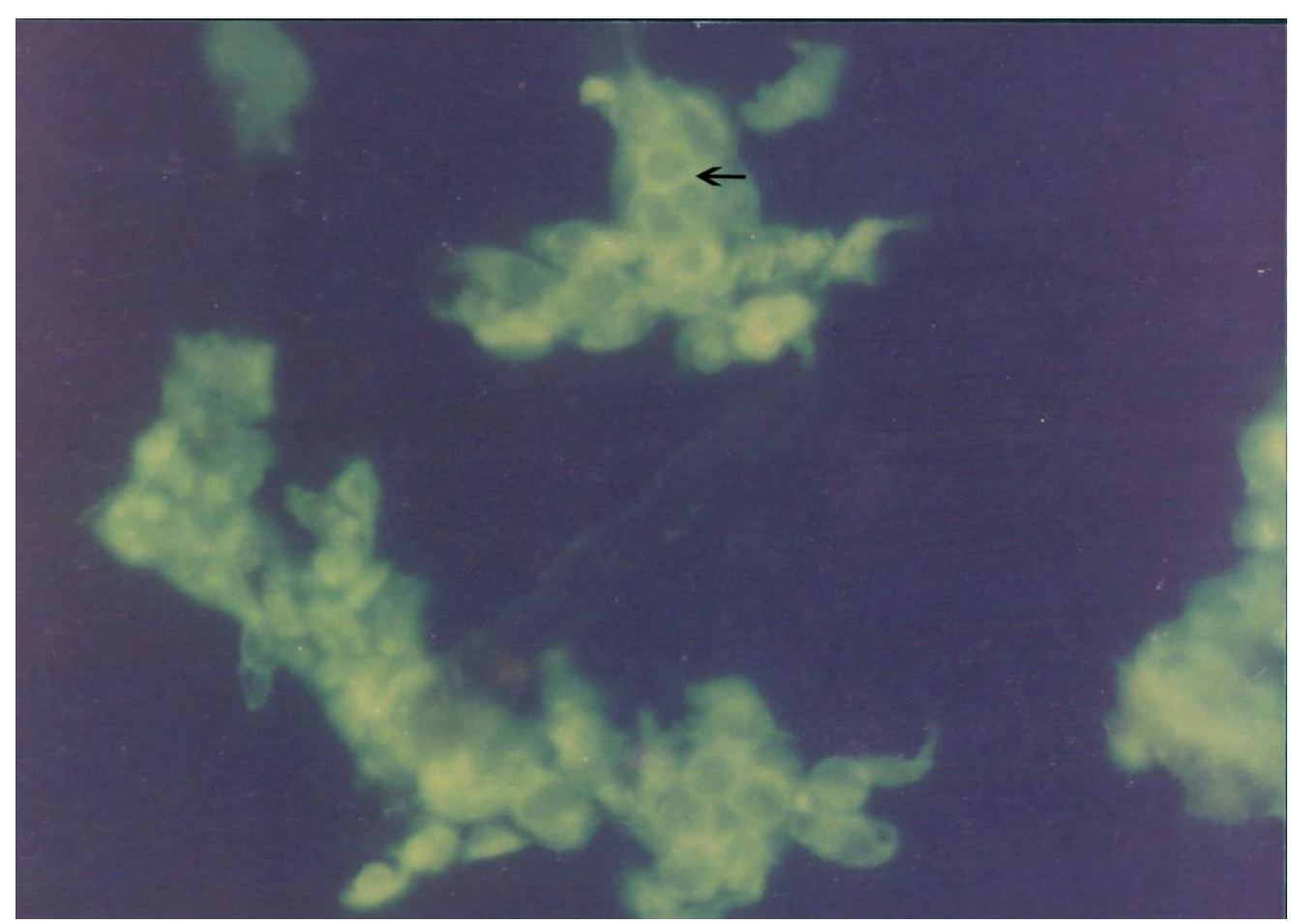

Fig. (1): Infected MDBK cells showed fine film of intracytoplasmic fluorescent greenish yellow granules (x 40).






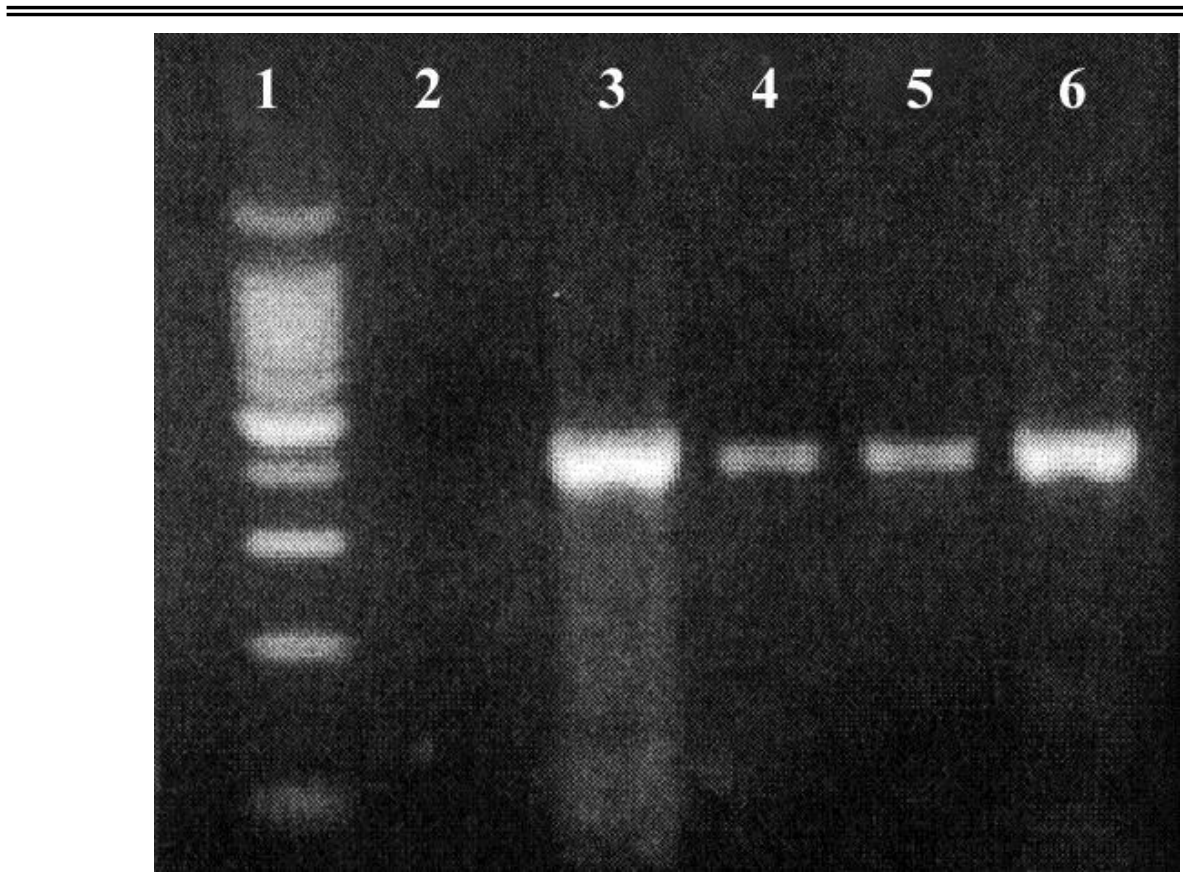

Fig.(2): Characteristic PCR positive bands of 730 bp size fragment of bovine coronavirus.

Lane $1: 100$ bp molecular marker

Lane 4-6 : suspected samples of bovine coronavirus

Lane 3 : positive control

Lane 2 : negative control

\section{DISCUSSION}

Due to spread of intestinal infections allover the world and the outcoming mortality, these infections along with severe diarrhea in many young animals are of great importance (Gumusora et al., 2007). In young calves, diarrhea is considered as one of the most important disease, because the resulting economic loss following mortality, treatment costs, and decrease of growth rate (Maes et al., 2003). 
Indeed, long-term effects of diarrhea on the health and efficiency of calves cured from clinical courses of the disease may cause more economic loss (Fuente et al., 1998). Coronavirus, Rotavirus, enterotoxigenic Escherichia coli, and cryptosporidium parvum are four major pathogens accompanied by diarrhea in young calves around the world. These organism are responsible for most of the intestinal infection (75-90\%) in young calves in the world (Athanassious et al., 1994, Fuente et al.,1998, Radostitis et al.,2007). Coronaviruses from wild ruminants can experimentally infect young calves (Tsunemitsu et al.,1995). In this study BCV antigen was detected in fecal samples of young calves by using RT-PCR and other serological diagnostic methods such as antigen-capture ELISA, direct FAT andHAT/HIT. HA titers ranged from 16-64 and this finding agreed with (Tsunemitsu et al.,1991), while the HI results were low in comparing to the other techniques revealing to its low sensitivity (Aline et al;2009).

Fluorescent antibody test (FAT) is moderately sensitive, rapid and allows detection and localization of virus infected cells. This assay may fail to detect infected enterocytes in calves in the later stages of infection (Anthony and Werner,1992) and tissues must be retrieved 4 to 6 hours after the onset of diarrhea because the infected villous epithelial cells are rapidly destroyed (De Beer et al., 1997).

ELISA is good for laboratories handling large numbers of specimens on daily basis (AL-Yousif et al., 2001, and Howe et al., 2008), sensitive and can be completed in less than 4 hours (De Beer et al., 1997). However, ELISA without limitations where highly specific antisera or monoclonal antibodies are required (Crouch et al.,1984 and El-Ghorr et al.,1988). In addition, false negative results can arise from 
the presence of blocking antibodies in the specimens (Reynolds $\boldsymbol{e t}$ al.,1984 and Dea and Garzon, 1991) or high concentration of fecal material (Crouch et al.,1985 and Dea and Garzon, 1991), while the presence of proteases lowers sensitivity (Dea and Tijssen, 1989).

RT-PCR is sensitive (Klein et al.,2008). The published primers for the nucleocapsid gene that was conserved among BCV strains. Our results showed that RT-PCR is applicable in detecting BCV in clinically normal calves. It allows for the application of preventative measures prior to the emergence of diarrhea on a farm. This is because the more sensitive RT-PCR assay may detect BCV-positive animals than might otherwise be classified as BCV- negative by ELISA, FAT, and HAT. When we used the RT-PCR method we observed that sensitivity increased. RT-PCR could detect $8 / 18$ of non diarrheic calves, but with using capture ELISA were able to detect only $5 / 18$ positive samples. Choe et al.(2001) reported that the sensitivity of RT-PCR and nested PCR compared with ELISA was very high, but that specificity was low.

In conclusion, WE can recommend to use RT-PCR as a rapid, accurate and sensitive diagnostic method for the BCV detection.

\section{REFERENCE}

- Aline F.B., Alice F.A., Danilo T.S.and Amauri.A.A.(2009): Bovine corona virus detection in acollection of diarrheic stool samples positive for group A-Bovine rota virus.

- Al-Yousife, Y.; Anderson, J.;Chard-Bergstrom, C. and Snjay, K. (2001): Development, evaluation and application of lateral-flow immunoassay (immunochromatagraphy) for detection of rotavirus in bovine fecal samples. Clin.Diag.Lab.Immunol.,9(3): 723-725. 
- Anthony, E.C. and Werner, P.H.E.(1992): Veterinary Diagnostic Virology : A practitioners guide, Mosby,St.Louis Missour.

- Athanassious R., Marsolais G., Assaf R., Dea S., Descoteaux J.P., Dulude S., Montpetit C.(1994): Detection of bovine coronavirus and type A Rotavirus in neonatal calf diarrhea and winter dysentery of cattle in Quebec : evaluation of three diagnostic methods. Can.Vet.J. 35:163-169.

- Cho. K.O.M.; Hasutsuz, P. R.; Nelsen, K. O.; Chang, S. and Lathrop, S. J. Saif, (2001): Cross protection studies between respiratory and calf diarrhea and winter dysentery coronavirus strains in calves and RT-PCR and nested PCR for their detection. Arch. Virol., 146, 2401-2419.

- Clark, M. A. (1993): Br. Vet. J., 149:51-70.

- Crouch C., Bielefeldt O.H., Watts T.C. and Babiuk L.A. (1985): Chronic shedding of bovine enteric coronavirus antigen antibody complexes by clinically normal cows. J.Gen.Virol., 66:1489-1500.

- Crouch C., Raybould T. and Acre, S.(1984): Monoclonal antibody capture enzyme linked immunosorbent assay for detection of bovine enteric coronavirus.J.Clin.Microbiol, 19:388-393.

- De Beer, M., Peenze, I., De Costa N.M. and Stecle A.A.(1997): Comparison electron microscopey, enzyme linked immunosorbent assay and latex agglutination for the detection of bovine rotavirus in faeces, J.S.Afr.Vet.Assoc.68:93-96.

- Dea S. and Garzon S.(1991): Identification of coronavirus by the use of indirect protein A- gold immunoelectron microscopy. J. Vet. Diagn. Invest, :297-305. 
- Dea,S.and Tijssen, P.(1989): Detection of turkey enteric coronavirus by enzyme-linked immunosorbent assay and differentiation from other coronaviruses. Am. J. Vet.Res., 50, 226-231.

- El-Ghorr A.A., Snodgrass D.R. and Scott F.M. (1988): Evaluation of an immunogold electron microscopy technique for detecting bovine coronavirus.J.Virol.Meth. 19:215-224.

- Fuente R., Garcia A., Ruiz-Santa-Quiteria J.A., Luzon M., Cid D, Garcia S., Orden J., Gomez-Bautista M.(1998): Proportional morbidity rates of enteropathogens among diarrheic dairy calves in central Spain. Prev. Vet. Med.36:145-152.

- Gumusova S.O., Yazici Z., Albayrak H., Meral Y.(2007): Rotavirus and coronavirus prevalence in healthy calves with diarrhea. Med.Wet. 63(1): 62-64.

- Hasey, D.; Reynolds, D. J. and Bridger, J. C. (1984): Identification of coronaviruses in exotic species of bovidae. Vet. Rec., 115:602-603.

- Hasuksuz, M.; Lathrop, S.; Al-Dubaib, A. ; Lewis, P.; Saif, J. (1999): Antigenic variation among bovine enteric coronavirus (BECV) and bovine respiratory coronavirus (BRCV) detected using monoclonal antibodies.Arch. Virol., 144, 2441-2447.

- Hasulksuz, M. A. E.; Hoet, S. C.; Loerech, T. E.; Wittum, P. R.; Nielsen, L.; Saif, J. (2002): Detection of respiratory and enteric shedding of bovine coronavirus in cattle in an Ohio feed lot. J. Vet. Diag. Invest., 14, 308-313.

- Howe, L.; Sugiarto, H. and Squires, R. (2008): Use of polymerase chain reaction for the differentiation of Group A bovine rotavirus G6, G8 and G10 genotypes in the North Island of New Zealand. NewZealand Vet. J., 56(5): 218-221 (4). 
- Klein, D.; Kern, A.; Lapan, G.; Benetka, V.; Mostl, K.; Hassl, A. and Baumgartner, W. (2008): Evaluation of rapid assays for detection of bovine corona virus, rota virus $\mathrm{A}$ and Cryptospordidum Parvum in faecal samples ofcalves. Vet. J. in Press.

- Lai, M. C.; and Cavanagh, D. (1997): Molecular biology of bovine coronavirus. Adv. Virus. Res., 48, 1-100.

- Lathrop S., Wittum T.E., Loerech S.C., Perinol .J. (2000): Association between infection of the respiratory tract attributable to bovine coronavirus and health and growth performance of cattle in feedlot. Am.J.Vet. Res. 61,1062-1066.

- Maes R.K., Grooms D.L., Wise A.G., Han C, Ciesicki V., Hanson L., Vickers M.J., Kanitz C , Holland R.(2003): Evaluation of a human group A Rotavirus assay for on-site detection of bovine rotavirus. J.Clin Microbiol 41:290-294.

- Payment, P. and Trudel, M. (1993): Methods and techniques in virology.Marcel, Dekker, New York.

- Quinn, P. J.; Markey, B. K.; Carter, M. E.; Donnelly, W. J. Leonard, F. C. (2002): Veterinary microbiology and microbial diseases, $1^{\text {st }}$ ed., Blackwell Science Publishing,. PP: 419-420.

- Radostitis O.M., Gay C.C., Hinchcliff K.W., Constable P.D.(2007): Veterinary Medicine, A text book of the disease of cattle, horses, sheep, pigs, and goats, $10^{\text {th }}$ edn. Saunders-Elsevier, Philadelphia, pp 1286-1296.

- Reynolds D.J., Chasey D., Scott A.C. and Bridger J.C. (1984): Evaluation of ELISA and electron microscopy for detection of coronavirus and rotavirus in bovine faeces. Vet.Rec. 21, 114(16): 397-401. 
- Saif, L. j. (1993): Coronavirus immunogens. Vet. Microbiol-37, 285-297.

- Saif, L. J. (1990): Cornell Vet., 80:303-311.

- Sato,K., Inab,Y., kurogi, H., Takahashi, E., Ito, Y., Goto, Y., Omori, T. and Matumot, M. (1977): physico-chemical properties of calf diarrhea coronavirus. Vet. Micob. 2:73

- Traven, M.; Naslund, K.; Linde, N.; Linde, B.; Silvan, A.; Fossum, C. Hedlund, K. O. and Sarsson, B. (2001): Vet. Microbiol., 81: 127-151.

- Tsunemitsu H., Smith D.R., Saif L.J. (1999): Experimental inoculation of adult dairy cows with bovine coronavirus and detection of coronavirus in feces by RT-PCR. Arch.Virol.144,167-175.

- Tsunemitsu H., Yonemichi H., Hirai T., KuDo T., Onoe S., Mori K., and Shimizu M.(1991): Isolation of bovine coronavirus from feces and nasal swabs of calves with diarrhea. J.Vet.Med.Sci.,53:433-437.

- Tsunemitsu, H.; El-Kanawati, Z, and Smith, D. (1995): Isolation of coronavirus antigenically indistinguishable from bovine coronavirus from wild ruminants with diarrhea. J. Clin. MIcrobiol., 33:3264-3269.

- Varies, A. A. f. m. c.; Horzinek, P. J. M.; Rottier, R. J. De Groot (1997): The genome organization of the Nidovirales: Similarities and differences between Arteri-Toro and coronavirus. Semin Virol., 8, 33-74. 


\section{استخدام اختبار البلمرة المتسلسل فى تشخيص فيروس الكورونا البقرى فى العجول المصابة بالإسهال فئن فئروس}

\section{ناهد احمد محمود هناء عبد العزيز محمد غنيم هالة عبد الرحيم سالم}

يعتبر فيروس الكرونا البقرى سبب رئيسى للإسهال الثديد لفصائل الحيوانات المختلفة. العجول حتى عمر 3 شهور تصـاب بالفيروس. أهمية هذا الفيروس ترجع الى الخسارة الإقتصادية، وتكاليف العلاج الباهظة وقلة معدل النمو فى عجول التسمين والحلاب.

تشبير هذه الدراسة إلى استخدام أربعة اختبارات تتخيصية وهى اختبار تثبط التلزن (HIT)

واختبار القلورسنت المناعي المشع المباشر واختبار الاليزا واختبار الاستتساخ العكسى لإختبار تفاعل انزيم البلمرة المنسلسل فى عينـات البراز لعجول مصـابة باسـهال (50 عينة) وعجول ليست مصـابة باسهال (18 عينة). كانت أعلى باستخدام اختبار تفاعل انزيم البلمرة المتسلسل في العجول المصابة ينسبة 84\% يليها اختبار الاليزا 67\% يليها اختبار القلورسنت المناعى 62\% ثم اختبار تثبيط التلزن 56\% وقد أوضحت الدراسة وجود الفيروس فى العجول الغير مصابة بالإسهال بنسب أقل وكانت النسب 4.44\% باستخدام اختبار RT-PCR ثم 27.7\% باختبار الاليزا ثم 2.22\% باختبار الفلورسنت المناعى و 1.11\% باستخدام اختبار التلزن المثبط. وتتشبر النتائج على أن اختبار RT-PCR هو الأكثر حساسية من الاختبارات التشخيصية الأخرى للكثف عن الفيروس خاصة فى العجول الني ليست عليها أعراض إسهال حيث أن العجول تفرز كمية قليلة من الفيروس في البراز نحتاج إلى اختبارات

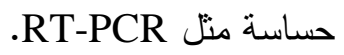


